\title{
ЗАКОНОМІРНОСТІ РАЦІОНАЛЬНОГО ВІДТВОРЕННЯ РЕСУРСНОГО ПОТЕНЦІАЛУ, ЯК УМОВА ЕФЕКТИВНОГО ФУНКЦІОНУВАННЯ АГРАРНОГО ПІДПРИЕМСТВА
}

\author{
Матвєєв Павло Миколайович \\ кандидат економічних наук \\ директор ТОВ «ЗЕМІНФОРМ»
}

\begin{abstract}
У статті визначено передумови кризової ситуації в аграрному секторі, встановлено, що основною ознакою виробництва є повторювальний характер виробничого циклу, наведено стадії суспільного виробництва. Охарактеризовано сутність та обов'язкову умову процесу відтворення, узагальнено еволюцію наукових поглядів на категорію відтворення в економічній системі, розкрито специфіку відтворення в аграрному секторі економіки, виділено склад критеріїв ресурсної забезпеченості аграрного виробниитва. Запропоновано методичний підхід для оиінювання рівня ресурсного забезпечення виробництва продукції рослинництва в сільськогосподарських підприємствах та критерії класифікації фракторів формування та розвитку систем техніко-технологічного забезпечення виробництва агропідприємствами продукиії рослинництва. Доведено, що метою механізму розвитку потенціалу підприємства є досягнення стійкого фрункціонування і розвитку підприємства в умовах циклічних процесів економіки.
\end{abstract}

Ключові слова: аграрне підприємство, сільське господарство, виробничий цикл, процес відтворення, техніко-технологічного забезпечення.

DOI: https://doi.org/10.32845/bsnau.2019.4.10

Постановка проблеми. Існування загальноекономічних диспропорцій, наслідки кризових явищ, несистемний характер проведення аграрних реформ та низка суб'єктивних причин призвели до суттєвого зниження ефективності основної діяльності, порушення галузевого балансу в агропромисловому виробництві, а також втрат та недостатньої результативності використання потенціалу сільськогосподарських підприємств. Результатом виникнення цих наслідків стали системні викривлення в протіканні відтворювальних процесів в вітчизняному сільськогосподарському виробництві. Підприємства аграрного сектора економіки України значною мірою характеризуються збитковістю виробництва, а отже неможливістю забезпечення навіть простого відтворення.

Аналіз останніх досліджень і публікацій. Розглядаючи питання раціонального відтворення ресурсного потенціалу у контексті ефрективного функціонування аграрного підприємства варто відзначити праці таких дослідників, як: Альбещенко О. С. [0], Должанський І. 3. [0], Кужель В. В. [0], Лагодієнко В. В. [0], Мягких І. М. [0], О. В. Собкевич, В. М. Русан, А. Д. Юрченко, О. В. Ковальова [0], Самойленко Т. Г. [0], Сокольська Т. В. [0] та ін.

Метою статті $\epsilon$ визначення закономірностей раціонального відтворення ресурсного потенціалу аграрних підприємств в умовах економічних зрушень, що відбувається в рамках глобаліхаційних та інтеграційних процесах світової економіки.

Виклад основного матеріалу. Основою життєдіяльності індивідуумів та суспільства, в цілому, є матеріальне виробництво. Саме в ньому створюються необхідні для існування людини предмети споживання. При цьому головною ознакою виробництва будь-якої продукції є повторювальний характер виробничого циклу. Тобто можна провести паралель між безперервним характером споживання благ, а отже безперервним та повторювальним характером їх виробництва. Отже, виробничий цикл як на макрорівні (в межах національної та світової економіки), так і на мікрорівні (в межах підприємства) має постійно повторюватись. В економічній науці саме безперервне повторення виробництва характеризується як відтворення.

Стадіями суспільного виробництва є: безпосередньо виробництво, розподіл, обмін і споживання продукції. ЦЦі чотири стадії утворюють постійний економічний кругообіг. Тобто виробництво постійно відновлюється через проходження цих стадій. Для цього процесу необхідне постійне відновлення всіх факторів виробництва: робочої сили, засобів виробництва та природних ресурсів. При цьому відновлення останніх - нагальна потреба відтворення в сучасних умовах інтенсифікації виробництва, передусім, в аграрному секторі економіки.

Обов'язковою умовою відтворювального процесу $є$ його натурально-речова частина у вигляді відновлення продуктивних сил. При цьому надзвичайного значення набуває проблема пропорційності - певних кількісних співвідношень між складовими суспільного виробничого циклу. При поновленні виробничого циклу необхідно не просто мати робочу силу і засоби виробництва, а співвідношення їх у конкретних пропорціях. Порушення пропорційності неминуче призводить до зниження ефективності виробництва.

У сільськогосподарському виробництві економічний процес відтворення незалежно від його суспільного характеру завжди переплітається з природним. Тому раціональне управління в цій галузі вимагає знань і вмілого використання не лише економічних законів, а й законів природи. Тісний взаємозв'язок економічних процесів з природними зумовлює значний вплив останніх на результати господарської діяльності, що впливає на темпи відтворення. Звідси можливість різкіших коливань темпів нагромадження порівняно з іншими галузями.

На відтворення в аграрному секторі економіки суттєво впливає родючість землі. В сільському господарстві земля $€$ головним засобом виробництва, при правильному використанні вона постійно відновлює свою родючість, більше того, якісно поліпшується. В результаті різниці в природних умовах, насамперед різної родючості землі, на відміну від інших галузей праця однакової кваліфікації та фондоозброєності 
дає різні результати, тобто продуктивність праці визначається тут передусім продуктивністю природних факторів.

Вплив природних факторів на результати виробництва можна обмежити розвитком продуктивних сил. Йдеться про економічну родючість, підвищення якої досягається через раціональне використання землі, систематичне впровадження нових технологій, досягнень науки і техніки, поліпшення культури землеробства тощо. Маючи таку властивість, як родючість, земля безпосередньо впливає на результативність виробництва, а та обставина, що вона підвищується, передбачає підвищення темпів відтворення. Родючість грунтів, природні та біологічні процеси справляють значний вплив на спеціалізацію виробництва, на поєднання окремих галузей сільського господарства. Оптимальне поєднання їх характеризується відповідною технологією виробництва і, як наслідок, визначеним набором засобів і предметів праці. У зв'язку з цим напрям капітальних і виробничих витрат в господарствах різної спеціалізації неоднаковий.

Визначення оптимального поєднання основних і допоміжних галузей вимагає формування відповідного виробничого потенціалу на основі досягнень науково-технічного прогресу з метою підвищення ефективності його функціонування, використовуючи ринкові механізми, що передбачає в сільському господарстві не просто використання техніки, а й створення системи машин. Остання повинна враховувати можливості й специфіку виробництва кожного виду продукції в їх поєднанні, виходячи з принципу максимального використання робочих машин, агрегатів транспортних засобів. Дуже важливо також забезпечувати максимальну кількість необхідних засобів виробництва в критичні строки з тим, щоб виконати всі роботи в оптимальний період і не допустити втрат врожаю внаслідок несвоєчасної оранки, боронування або затримки під час посіву чи збирання врожаю тощо. Тому в сільському господарстві необхідна більш висока насиченість його засобами виробництва, більш висока фрондо- і енергоозброєність праці.

Особливістю відтворення в аграрному секторі економіки є те, що частина продукту виробництва може бути використана безпосередньо для розширення виробництва як його умови, не набуваючи товарної форми. Це обумовлено тим, що виготовлений продукт, у тому числі й додатковий, не відрізняється за своєю споживчою вартістю від засобів виробництва, які функціонують у процесі виробництва. Також це визначається характером споживчої вартості: вона входить у виробництво як його умова в певному підприємстві, якому належить, чи якому буде реалізована. У зв'язку з тим процеси нагромадження та розширеного відтворення на практиці збігаються.

Особливості відтворення в аграрному секторі економіки визначаються тим, що технічний прогрес не обмежується рамками машинної техніки. Рослини і тварини виступають як предмети праці і знаряддя праці, а земля $є$ головним засобом виробництва. Тому одним 3 найважливіших напрямів розвитку аграрного виробництва $є$ виведення високоврожайних сортів сільськогосподарських культур і високопродуктивних порід тварин, впровадження у виробництво заходів, які забезпечують підвищення родючості землі, що становить сутність агротехнічного і зоотехнічного прогресу.

Підвищення технічної забезпеченості сільськогосподарського виробництва в поєднанні з використанням високоврожайних культур і високопродуктивних тварин $є$ основою підвищення ефективності виробництва. Якість сільськогосподарських робіт значною мірою визначається досконалістю техніки, що впливає на врожайність культур. В свою чергу, нові, якісніші та більш врожайні сорти культур вимагають досконаліших і ефективніших машин, які слід використовувати в процесі виробництва. Ця відповідність забезпечує максимальний есрект прогресивної технології виробництва, що є основою швидких і сталих темпів відтворення.

Більшість дослідників дотримуються однозначного уявлення, що об'єктами відтворювального процесу є фактори виробництва, а його суб'єктами виступають суб'єкти господарської діяльності або їх сукупності, сфрормовані по галузевим, продуктовим, територіальним та іншим принципам.

В сільськогосподарському виробництві, як і в будьякому іншому виробничо-комерційному процесі, поєднуються засоби виробництва, предмети праці та процес праці для отримання певного результату, що має забезпечувати розширене відтворення капіталу підприємств-виробників. Основними ресурсами сільськогосподарського виробництва в галузі рослинництва є: земельні ресурси; матеріально-технічні ресурси; трудові ресурси; фінансові ресурси; інформаційні ресурси.

При цьому процес відтворення ресурсів в аграрному виробництві, зокрема, рослинництві, при реалізації виробничих процесів $є$ досить специфічним у порівнянні з іншими галузями національної економіки. Процес відтворення носить не тільки фінансовий (матеріальний), а й екологічний характер, адже основним ресурсом аграрного виробництва в рослинництві є земельні ресурси, стан яких віддзеркалюється не тільки на ефективності процесів аграрного виробництва, а й на стані зовнішнього середовища взагалі. До того ж, відтворення родючості ґрунтів сільськогосподарського призначення при нераціональному їх використанні потребує великих витрат часу та матеріальних ресурсів.

Трудові ресурси є важливим ресурсом виробничого процесу, адже вони являють собою виробничий персонал, що безпосередньо виконує основні та допоміжні технологічні операції. Важливість цього ресурсу зумовлюється демографічними проблемами, а саме невигідним співвідношенням сільського та міського населення, яке $є$ наслідком масового відтоку кваліфікованих кадрів з сільської місцевості та загальним рівнем старіння населення.

Матеріально-технічні ресурси виробничого процесу опосередковуються в основних та оборотних засобах аграрних підприємств. Склад основних засобів, особливо активної їх частини, визначає можливість виконання необхідних для якісної реалізації виробничого процесу технологічних операцій, а разом з трудовими ресурсами, що залучаються, та організаційно-управлінськими заходами формують рівень технології та культуру виробництва на підприємстві. Оборотні засоби аграрних підприємств втілюються в матеріальних та нематеріальних витратах, основними з яких є витрати на утримання та експлуатацію сільськогосподарської техніки, закупівлю насіннєвих матеріалів, добрив, засобів захисту рослин та оплату праці персоналу підприємства.

Наявність фінансових ресурсів дозволяє виробникам сільськогосподарської продукції забезпечити виробництво необхідними матеріально-технічними ресурсами в повному обсязі. 
Інформаційні ресурси аграрного виробництва включають системи маркетингової, технологічної, виробничо-організаційної, правової та іншої інформації. Система маркетингової інформації є основою формування оптимальної політики збуту продукції підприємства та раціонального витрачання коштів, які зв'язуються в придбанні матеріальних ресурсів, що врешті-решт зумовлює ефективність діяльності підприємства в короткостроковому періоді. Оптимальність системи маркетингової інформації залежить не стільки від якості організації роботи відповідних служб підприємства, скільки від рівня розвитку відповідних товарних ринків: сільськогосподарської продукції та матеріальних ресурсів сільськогосподарського виробництва.

Система технологічної інформації має сприяти раціональній роботі агрономічної та інженерної служб підприємства, містити повну картину про стан земельних ресурсів та технологічні можливості підприємства в ході виробництва основної продукції. Виробничо-організаційна інформація служить основою для загального керівництва роботою підприємства та має дозволяти раціональну розстановку та витрачання ресурсів виробничого процесу. Оптимально побудована система правової інфрормації дозволяє підприємству своєчасно реагувати на зміни в правовому полі ведення діяльності та уникати за рахунок цього небажаних фінансових та часових втрат.

Рівень і динаміку показників ефрективності виробництва в залежності від ресурсозабезпеченості визначають різними методами. Одним із надійних є метод економічного групування в залежності від ресурсного потенціалу: трудові ресурси, виробничі фонди, сільськогосподарські угіддя. Проте, ми наполягаємо на необхідності поглиблення конкретизації складових ресурсного забезпечення виробничої діяльності сільськогосподарського підприємства, що і було проілюстровано вище.

При цьому в якості центральної складової ресурсного забезпечення ми розглядаємо фрінансові ресурси, які можуть опосередковуватися та формувати всі інші види ресурсів, необхідних для забезпечення протікання виробничих процесів. Формування ресурсного, в тому числі і фрінансового забезпечення виробництва сільськогосподарської продукції, зокрема, продукції рослинництва, є процесом реалізації виробничого потенціалу суб'єкта господарювання. При здійсненні управлінського впливу на цей процес виникає методична задача оцінки потенціалу підприємства, яка може вирішуватися в різний спосіб.

Як вже зазначалося, всі об'єкти відтворювального процесу мають певний фінансовий еквівалент, а отже можуть бути опосередковані у вигляді фрінансових ресурсів підприємства. Зауважимо, що фінансові ресурси підприємств опосередковуються поряд з іншими видами ресурсів також і у формуванні елементів техніко-технологічного забезпечення виробництва, яке складає основу реалізації та інтенсифікації виробництва продукції рослинництва.

Беззаперечною в даному контексті та з урахуванням найбільш поширених наукових поглядів на економічний механізм аграрного виробництва $є$ наукова позиція Б.Й. Пасхавера, який зазначає, що «визначаючи необхідну (відтворювальну ціну) для виробника, сьогодні важливо забезпечити не тільки прибутковість, а насамперед і технологічно раціональ- ний фонд відшкодування. Важлива складова ціни відтворювального рівня - повноцінне відшкодування спожитого основного капіталу, тобто амортизаційні відрахування у розмірах, здатних компенсувати фізичний та моральний знос основних засобів» [Помилка! Джерело посилання не знайдено., C. 54].

Раціональність використання оборотних засобів дозволяє максимізувати результативність агробізнесу, а отже формувати необхідні обсяги прибутку для подальшого реінвестування у виробництво, в тому числі і в оновлення активної частини основних засобів сільськогосподарських підприємств. Оцінку ресурсного забезпечення аграрного виробництва в підприємстві, на нашу думку, доцільно виконувати в розрізі таких значущих його складових, як активна частина основних засобів та кошти для фінансування оборотних засобів. Отже, кількісними та якісними параметрами стану ресурсного забезпечення аграрного виробництва, зокрема, виробництва продукції рослинництва, є: обсяги відновлення оборотних засобів; обсяги рефінансування прибутку в виробничий процес; склад машинно-тракторного парку. Враховуючи вказані параметри можна виділити склад критеріїв ресурсної забезпеченості аграрного виробництва, а саме:

1. Ступінь забезпеченості виробничого процесу активною частиною основних засобів.

2. Ступінь забезпеченості коштами для фрінансування матеріальних та нематеріальних витрат при реалізації процесу виробництва продукції.

Відповідність ситуації, що склалася в підприємствах, вказаним критеріям характеризує його здатність ефективно, при оптимумі витрат, виробляти максимальний обсяг конкурентоспроможної сільськогосподарської продукції. На сьогоднішній день, в аграрному секторі АПК оперують суб'єкти господарювання різних організаційно-правових форм, масштабів та такі, що мали різні стартові умови ведення своєї діяльності. Саме це організаційно-економічне підгрунтя разом зі здобутками організації та управління поточною діяльністю визначають фактичний стан ресурсного забезпечення функціонування підприємств галузі.

Застосований нами підхід ґрунтується на виділенні чотирьох рівнів ресурсного забезпечення виробництва продукції рослинництва в сільськогосподарських підприємствах, а саме: високого, достатнього, задовільного та низького. В якості критеріїв віднесення сільськогосподарських підприємств до тієї чи іншої групи за рівнем ресурсного забезпечення нами були використані питомі (на одиницю площі) показники вартості основних фрондів та обсягу виручки від реалізації продукції. При цьому обсяг виручки від реалізації ми розглядаємо як джерело фінансування, передусім, оборотних засобів.

Розв'язання задачі створення умов для фрормування оптимальної системи ресурсного забезпечення виробництва продукції рослинництва слід починати з виявлення реального стану ресурсної бази виробників сільськогосподарської продукції. Отже, врахування запропонованих критеріїв дозволятиме, на наш погляд, надавати достовірну оцінку стану ресурсного забезпечення сільськогосподарських підприємств.

Слід також зазначити, що найбільше значення для забезпечення ефективності процесів відтворення в економіці аграрних підприємств має не стільки наявність ресурсів, скільки їх оптимальна, для вирішення задач, що стоять перед 
підприємством, комбінація. Запропонований методичний підхід дозволяє не тільки визначити та класифікувати стан ресурсного забезпечення, а також надати оцінку комбінації ресурсів підприємства.

Технічні засоби сільськогосподарських підприємств уособлюються у складі та структурі їх машинно-тракторного парку. Сучасний стан машинно-тракторного парку більшості вітчизняних сільськогосподарських підприємств характеризується такими властивостями:

1. Низьким ступенем технічної готовності машиннотракторних агрегатів.

2. Високою питомою вагою застарілої техніки в структурі машинно-тракторного парку.

3. Невідповідністю існуючої структури машинно-тракторного парку задачам впровадження прогресивних технологічних рішень в сільськогосподарському виробництві.

При цьому машинно-тракторний парк, як частина основних засобів підприємства, є об'єктом відтворення. Проте, розгляд тільки технічних засобів, як складової ресурсного потенціалу сільськогосподарських підприємств, відокремлено від технологій є обмеженим та однобічним, адже метою придбання тих чи інших об'єктів технічних засобів $є$ реалізація певних технологічних процесів, а у найкращому випадку - їх якісне вдосконалення. Отже, відтворення технічних засобів $€$ запорукою розвитку агровиробництва, інструментом якого $є$ вдосконалення технологій, яке, в свою чергу, не є можливим без якісних та кількісних зрушень у складі об'єктів технічних засобів. Тому, на нашу думку, в якості складової виробничого потенціалу підприємства доцільно розглядати, безпосередньо, техніко-технологічне забезпечення, яке має ознаки системності, а саме: цілісність та ділимість, наявність стабільних зв'язків, організацію та емерджентність. При цьому наполягаючи на системному характері техніко-технологічного забезпечення, до категоріального інструментарію нашого дослідження доцільним $€$ введення поняття «система техніко-технологічного забезпечення виробництва продукції підприємства». Основою формалізації цього поняття є трактування категорії «система».

Втім, безмежно довго можна наводити визначення загальнонаукової категорії «система», проте, всі вони збігаються в тому, що системою є взаємопов'язана сукупність елементів, властивості яких доповнюють одна одну та створюють нові властивості, притаманні системі, як цілісному об'єкту. В контексті нашого дослідження техніко-технологічне забезпечення виробництва продукції сільськогосподарським підприємством, зокрема, продукції рослинництва є системою. Елементами даної системи $є$ технічні засоби та технології. При цьому технічні засоби є об'єктом відтворення, технологія $€$ інструментом використання техніки, а підприємство, в свою чергу, є суб'єктом відтворення, в тому числі і технічних засобів.

Слід зауважити, що техніко-технологічне забезпечення виробництва продукції рослинництва одночасно є системою і процесом, а дію системоутворюючих факторів можливо розглядати тільки в динаміці. В даному контексті актуалізується питання формалізації прояву цих факторів, який опосередковується в дії економічного механізму формування систем техніко-технологічного забезпечення виробництва продукції.

Формування системи техніко-технологічного забезпечення виробництва продукції є складовою відтворювального процесу, а характеристики процесу формування цієї системи, передусім, $є$ наслідком типу відтворення, що склався в підприємстві. Тобто формування та функціонування системи техніко-технологічного забезпечення відбувається у внутрішньому середовищі підприємства під впливом чисельних факторів мікро- та макросередовища, при чому центральним фактором є існуючий характер відтворювального процесу.

Основними факторами макросередовища є:

стан ринку сільськогосподарської техніки, а саме його характеристики, що визначають її наявність та доступність для придбання споживачами;

регуляторна та фіскальна політика держави, яка визначає тенденції капіталізації підприємств аграрного сектора; інвестиційний клімат галузі рослинництва, який визначає приток коштів з інших сфер економічної діяльності в розвиток підприємств галузі;

досягнення науково-технічного прогресу, які визначають впровадження у сільськогосподарське виробництво нових технологій та зразків техніки;

кредитна політика банків та інших суб'єктів ринку фінансових послуг, яка визначає можливість та доступність залучення безпосередніми товаровиробниками кредитних ресурсів в оновлення складу технічних засобів.

В свою чергу, фракторами мікросередовища є:

технічна політика підприємства, яка $€$ концептуальним втіленням підходу підприємства до реалізації агрономічних та технологічних характеристик;

товарна політика підприємства, яка є основною складовою його маркетингової політики та основним чинником формування програми виробництва;

характер протікання відтворювального процесу, який визначає формування потенційних можливостей та фінансового забезпечення діяльності підприємства.

Визначений склад основних факторів досить по-різному впливає на протікання процесів формування системи техніко-технологічного забезпечення агропідприємств. Дія одних фракторів більш інтенсивно проявляється в короткостроковому періоді, інших - в довгостроковому, одні фактори впливають на системи техніко-технологічного забезпечення агропідприємств системно, вплив інших є стохастичним, виникнення динаміки певних факторів носить об'єктивний характер, інших - суб'єктивний, більш того, для одних з них зворотній вплив організаційно-управлінських заходів підприємства чи інших суб'єктів інституційного середовища аграрної сфрери економіки $€$ вагомим, а інші характеризуються відсутністю будь-якої можливості управлінського втручання. Виходячи з зазначеного, класифікація факторів формування систем техніко-технологічного забезпечення агропідприємств виключно шляхом виділення фракторів макро- та мікросередовища недостатньою мірою відображає сутність процесу еволюції цих систем та, відповідно, обмежує окреслення перспектив їх розвитку.

Зважаючи на вказані обставини, ми пропонуємо класифрікувати фактори формування та розвитку систем технікотехнологічного забезпечення виробництва агропідприємствами продукції рослинництва за такими критеріями: 1) за інтенсивністю прояву дії факторів; 2) за системними ознаками; 3) за динамічними ознаками.

До активних за критерієм інтенсивності впливу можна віднести такі фактори внутрішнього середовища, як характер відтворення та товарну політику, адже перший з них визначає

Вісник Сумського національного аграрного університету 
можливості успішного фінансування технічного оновлення, а другий безпосередньо визначає необхідність залучення тих чи інших технічних засобів для реалізації відповідних технологічних процесів. В свою чергу за даним критерієм такий фактор мікросередовища, як технічну політику підприємства, можна класифікувати як пасивний, адже в сучасних умовах далеко не завжди суб'єкт господарювання має в своєму розпорядженні достатні фінансові ресурси для реалізації раціональної політики свого технічного розвитку, хоча й цілком усвідомлює найбільш доречний напрям цього розвитку.

За критерієм системності формування та впливу доцільно віднести до системних такі фактори мікросередовища, як характер відтворення та технічну політику, товарна ж політика підприємства здійснює, скоріше, стохастичний вплив на систему техніко-технологічного забезпечення, адже знаходиться під впливом чисельних факторів комерційного середовища підприємства, зміна яких лежить поза сферою впливу суб'єкта господарювання.

Фактори мікросередовища підприємства за динамічними ознаками доцільно класифікувати шляхом поділу на об'єктивні та суб'єктивні. При цьому до об'єктивних слід відносити існуючий характер протікання відтворювальних процесів в економіці підприємства, а до суб'єктивних - технічну та товарну політику, адже вплив першого з названих фракторів на розвиток процесу адаптації складу технічних засобів виробничим задачам підприємства характеризується повністю об'єктивними обставинами. В свою чергу, товарна та технічна політика формується менеджментом товаровиробника, рівно як ним же і опосередковується, а отже, має чітко виражений суб'єктивний характер.

Дещо складніша ситуація має місце із класифікацією факторів макросередовища, проте запропонований нами підхід відповідає характеру задачі пояснення процесу формування та розвитку систем техніко-технологічного забезпечення виробництва продукції рослинництва в агропідприємствах. Слід звернути увагу на те, що до групи активних факторів за критерієм інтенсивності впливу, тобто дія яких проявляється в короткостроковому періоді, в якості котрого доцільно розглядати тривалість одного виробничо-комерційного циклу, ми відносимо лише регуляторний вплив держави та кредитну політику учасників фінансового ринку, усі ж інші значимі фактори проявляють свою дію у довгостроковому періоді та створюють певний організаційно-економічний фон, на якому відбуваються окремі зрушення в діяльності певних підприємств, а отже процес розвитку систем техніко-технологічного забезпечення агровиробництва. При цьому всі визначені фактори макросередовища, крім інвестиційного клімату, є системними за другим критерієм. Нестабільний вплив інвестиційного клімату ми розглядаємо в контексті поведінки підприємства в частині формування системи техніко-технологічного забезпечення, адже залучення інвестиційних ресурсів на мікрорівні є, значною мірою, наслідком відповідної поведінки підприємства. 3 тих же причин ми розглядаємо інвестиційний клімат в якості суб'єктивного фактору за динамічними критеріями, в той час як всі інші фактори макросередовища розглядаються нами в дослідженні як об'єктивні.

Висновок. Розвиток потенціалу підприємства припускає позитивну зміну сутнісних характеристик потенціалу шляхом оптимізації його активно-пасивної структури в умовах фаз циклічного розвитку економіки для досягнення стійкого функціонування і розвитку підприємства. Досягнення стійкого функціонування і розвитку підприємства в умовах циклічних процесів економіки є метою механізму розвитку потенціалу підприємства. Стійкість підприємства визначається відносно його функціонування та можливих перспектив розвитку. Отже вона розглядається як можливість системи зберігати запланований розвиток незважаючи на зміни внутрішніх та зовнішніх чинників впливу та їх форм прояву. Ігнорування перешкод та можливість їх подолання поряд з збереженням внутрішніх характеристик є важливою властивістю протидії перешкодам. Таким чином, певна сукупність перешкод і передумов розвитку потенціалу підприємств дозволила визначити найбільш актуальні проблемні сфрери, актуалізувати і сфокусувати увагу на основних проблемах потенціалу підприємств. Визначене проблемне коло питань дозволило виділити основні напрями вирішення проблеми формування і розвитку потенціалу підприємств, формування системи його інструментарію, обґрунтувати необхідність створення концепції підтримки і розвитку потенціалу підприємств.

\section{Список використаної літератури:}

1. Альбещенко О. С. Теоретико-методичні аспекти раціонального використання земельно-ресурсного потенціалу сільських територій. / О. С. Альбещенко // Економіка та управління національним господарством. - 2017. - Випуск 16. - С. 98-102.

2. Должанський І. 3. Управління потенціалом підприємства : [навч. посіб.] / І. З. Должанський. - К. : ЦУЛ, 2006. - 368 с.

3. Кужель В. В. Потенціал підприємств аграрної сфери: сутність, структура, тенденції нарощення / В. В. Кужель // АгроСвіт. - 2013. - № 13. - С. 47-50.

4. Лагодієнко В. В. Концептуальна модель розвитку регіонального агропромислового виробництва / В. В. Лагодієнко // Глобальні та національні проблеми економіки. - 2015. - № 8. - С. 1259-1262.

5. Мягких І. М. Аналіз та оцінка використання ресурсного потенціалу в системі споживчої кооперації / І. М. М'яких // Актуальні проблеми економіки. - 2013. - №1(91). - С. 136-142.

6. Ресурсний потенціал аграрної сфери: проблеми та завдання ефективного використання : аналіт. доп. / О. В. Собкевич, В. М. Русан, А. Д. Юрченко, О. В. Ковальова [та ін.]. - К. : НІСД, 2013. - 76 с.

7. Самойленко Т. Г. Ресурсний потенціал сталого економічного розвитку сільських територій / Т. Г. Самойленко // Науковий вісник Херсонського державного університету. Серія Економічні науки. - 2015. - Вип. 15. - Частина 3. - С. 39-42.

8. Сокольська Т. В. Відтворення ресурсного потенціалу агросфрери як чинника економічного зростання / Т.В.Сокольська // Науковий вісник херсонського державного університету. - 2014. - Вип.3. - Ч.1. - С.272-275. 
Matvieiev P. M., PhD, Director of «Zeminform» LLC enterprise.

The regularities of resources potential rational reproduction as a condition of efficient functioning of an agrarian

The main trends that led to the crisis in the agricultural sector are outlined. The consequences of this crisis impact on the enterprise activity of the domestic agro-industrial sector are determined. It is established that the main feature of production is the repetitive nature of the production cycle. The stages of social production are given. It describes the nature and the prerequisite for the reproduction process. The evolution of scientific views on the category of «reproduction» in the economic system is generalized. The relationship between economic and natural reproduction processes is noted. The determining role of soil fertility in the reproduction process is substantiated. The specific features of reproduction in the agricultural sector of the economy are characterized. The resources involved in the process of reproduction in agriculture are identified: logistical, financial, information resources. The method of production efficiency estimation depending on resource availability is substantiated. Financial resources have been identified as a central component of resource provision. It is noted that all the objects of the reproduction process have a certain financial equivalent. The criteria composition for resource provision of agricultural production is highlighted. A methodological approach is proposed to evaluate the level of resource support for crop production in agricultural enterprises. The characteristics of the current state of the machine and tractor fleet of most domestic agricultural enterprises are characterized. It is proposed to consider the technical and technological support of the agricultural enterprise from the standpoint of systemic and process approaches. The main factors that influence the system of technical and technological support are outlined. The criteria of factors classification of formation and development of technical and technological support systems of crop production by agro-enterprises are offered. It is proved that the mechanism purpose of enterprise potential development is to achieve stable functioning and development of the enterprise in the conditions of economy cyclical processes. The essence of enterprise sustainability is determined.

Key words: agrarian enterprise, agriculture, production cycle, reproduction process, technical and technological support.

Дата надходження до редакції: 17.10 .2019 р. 